\title{
Poemas de Mina Loy
}

Virna Teixeira

\author{
OMEN OF VICTORY
}

\author{
Women in uniform \\ relaxed for tea \\ under a shady garden tree \\ discover \\ a dove's feather \\ fallen in the sugar.
}

\section{PRESSÁGIO DE VITÓRIA}

Mulheres de uniforme

tranqüilas para o chá

sob uma árvore sombreada do jardim

descobrem

uma pena de pombo

caída no acúçar. 
TEIXEIRA, Virna. Poemas de Mina Loy

\title{
MARBLE
}

Greece has thrown white shadows

sown

their eyeballs with oblivion

\author{
A flock of stone \\ Gods \\ perched upon pedestals
}

A populace
of athlete lilies
of the galleries

scoop the facades for space

with spiral curves

of idol substance

in the silence
A colonnade
Apollo haunts apollo
with the shade
of a lost hand 


\section{MÁRMORE}

Grécia arremessou sombras brancas

semeou

seus globos oculares com oblívio

Um rebanho de pedra

Deuses

empoleirados sobre pedestais

Uma população

de lírios de atletas

das galerias

escava como fachadas por espaço

com curvas espirais

da substância do ídolo

no silêncio

Uma colunata

Apolo caça Apolo

com a sombra

de uma mão perdida 
TEIXEIRA, Virna. Poemas de Mina Loy

Gertrude Stein

Curie
of the laboratory
of vocabulary
she crushed
the tonnage
of consciousness
congealed to phrases
to extract
a radium of the word

Gertrude Stein

Curie

do laboratório

do vocabulário

ela esmagou

a tonelagem

da consciência

coagulada em frases

para extrair

um rádio da palavra 


\section{POE}

a lyric elixir of death

embalms

The spindle spirits of your hour glass loves

On moon spun nights

sets

icicled canopy

for corpses of poetry

with roses and northern lights

Where frozen nightingales in ilix aisles

sing burial rites 
TEIXEIRA, Virna. Poemas de Mina Loy

\section{POE}

um elixir lírico da morte

embalsama

os espíritos do eixo dos seus amores de ampulheta em noites claras de luar

solidifica

dossel de pingentes de gelo

por corpos de poesia

com rosas e luzes do norte

Onde rouxinóis congelados em corredores de vertigem

cantam ritos fúnebres 


\section{TIME-BOMB}

The present moment

is an explosion,

a scission

of past and future

leaving

those valorous disreputables

the ruins,

sentinels

in an unknown dawn

strewn with prophecy.

Only the momentary

goggle of death

fixes the fugitive

momentum . 
TEIXEIRA, Virna. Poemas de Mina Loy

TEMPO-BOMBA

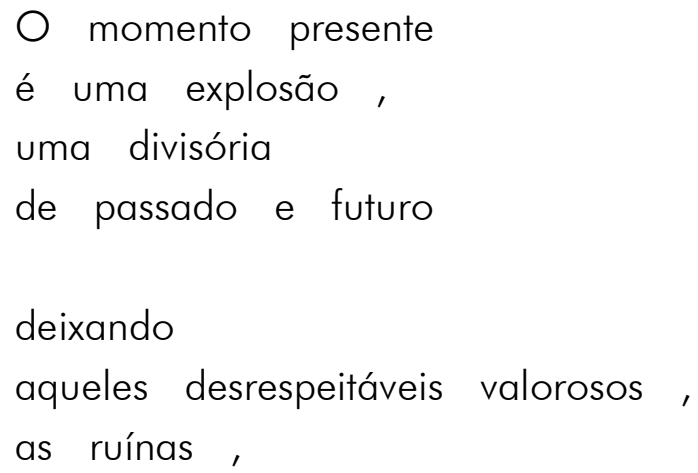


O HeLL

To clear the drifts of spring

Of our forebear's excrements

And bury the subconscious archives

Under unaffected flowers

Indeed-

Our person is a covered entrance to infinity

Choked with tatters of tradition

Goddesses and young Gods

Caress the sanctity of Adolescence

In the shaft of the sun. 
TEIXEIRA, Virna. Poemas de Mina Loy

$$
\text { OH INFERNO }
$$

Limpar as nevascas da primavera

Dos excrementos dos nossos ancestrais

E enterrar os arquivos inconscientes

Sob simples flores

Além disso-

Nossa pessoa é uma entrada coberta para infinidade

Sufocada com fiapos da tradição

Deusas e Jovens Deuses

Acariciam a santidade da Adolescência

Nos raios do sol. 


\section{SOBRE A AUTORA}

Mina Loy (1882-1966) nasceu em Londres, onde estudou artes plásticas, tendo obtido algum sucesso com suas pinturas, que chegaram a ser expostas no Salon d'Automne em Paris. Em 1916 mudou para a América, onde conheceu Marcel Duchamp e o grupo Dada de Nova lorque. Extremamente controversa, foi rotulada de futurista, dadaísta, surrealista, conceitualista, modernista e pós-modernista. Excêntrica, "difícil" e visionária, tinha entre seus admiradores Ezra Pound, Marianne Moore, Gertrude Stein e William Carlos Williams. Publicou apenas dois livros e tornou-se reclusa nos seus últimos anos de vida. Morreu em 1966, antes de terminar uma biografia sobre Isadora Duncan.

\section{SOBRE A TRADUTORA}

Virna Teixeira nasceu em Fortaleza em 1971. Mora em São Paulo. Tem dois livros de poesia publicados, Visita (2000) e Distância (2005) pela editora 7 Letras e colabora regularmente em várias revistas literárias como tradutora. 